\title{
Detection of human-induced environmental disturbances in a show cave
}

\author{
Angel Fernandez-Cortes $\cdot$ Soledad Cuezva $\cdot$ Sergio Sanchez-Moral \\ Juan Carlos Cañaveras - Estefania Porca * Valme Jurado * \\ Pedro Maria Martin-Sanchez - Cesareo Saiz-Jimenez
}

\begin{abstract}
Purpose We investigated the effects of human-induced disruption in a subterranean stable environment containing valuable Palaeolithic paintings and engravings (Ardales Cave, Southern Spain) using a double analytical approach. Methods An environmental monitoring system was installed in the cave to record temperature, relative humidity, carbon dioxide $\left(\mathrm{CO}_{2}\right)$ and radon $\left({ }^{222} \mathrm{Rn}\right)$ concentrations in air. In the same stations, an aerobiological sampling was conducted to quantify the level of airbome microorganisms. Results The combination of different methods allowed us to detect the extent of human-induced changes, confirming that these can be very hazardous in certain cave areas that should be apparently outside the scope of human disturbances, either by their remoteness to the visitor entrance or by being briefly visited.

Conclusions The detection of evident anomalies in the environmental parameters and airbome microorganism concentration in the cave area housing the high density of
\end{abstract}

\author{
A. Fernandez-Cortes $\cdot$ S. Cuezva $\cdot$ S. Sanchez-Moral \\ Museo Nacional de Ciencias Naturales, MNCN-CSIC, \\ Jose Gutierrez Abascal 2, \\ 28006 Madrid, Spain \\ J. C. Cañaveras \\ Laboratorio de Petrologia Aplicada, Departamento de Ciencias \\ de la Tierra y del Medio Ambiente, Universidad de Alicante, \\ 03080 Alicante, Spain \\ E. Porca V. Jurado + P. M. Martin-Sanchez * \\ C. Saiz-Jimenez (D) \\ Instituto de Recursos Naturales y Agrobiologia de Sevilla, \\ IRNAS-CSIC, \\ Apartado 1052 , \\ 41080 Sevilla, Spain \\ e-mail: saiz@imase.csic.es
}

paintings and engravings helps to control human disturbances and supports the direct application of this double approach for cave management purposes.

Keywords Aerobiology · Caves - Environmental control . Fungi $\cdot$ Bacteria

\section{Introduction}

Many subterranean sites, such as caves, mines, tunnels or catacombs, house geological, biological and/or historical elements which are considered natural and cultural heritages (Hill and Forti 1997; Sanchez-Moral et al. 2005). Caves usually show a stable and fragile confined environment that makes it very susceptible to disturbances resulting from human activities. In the case of subterranean sites impacted by tourism, it is necessary to determine the areas affected by human activity and the type and level of disturbance. Previous studies indicate that a scientific knowledge of the environmental parameters (temperature, humidity, $\mathrm{CO}_{2}$ ) are key factors in the conservation of the environment being crucial the separation between environmental changes due to natural causes and those resulting from human action (Huppert et al. 1993; Femandez-Cortes et al. 2006; Faimon et al. 2006). One of the most evident impacts of visitors in subterranean environments is the increase of $\mathrm{CO}_{2}$ concentration, water vapour and temperature (Andrieux 1988; Hoyos et al. 1998). This results in the interruption of the fragile geochemical/environmental balance and provokes mineral corrosion (Sanchez-Moral et al. 1999; Dreybrodt et al. 2005) and microbial colonization of rock substrata (Sanchez-Moral et al. 2005; Bastian et al. 2010). However, less known are the direct impact of visitors regarding microbial dispersion, the replacement of 
the natural microbial communities by alien human-induced microbial populations (Bastian et al. 2009) or the pool of pathogenic microorganisms thriving inside the caves (Jurado et al. 2010).

Recently, some studies on airbome bacteria and fungi have been carried out in indoor environments (Rintala et al. 2008; Wang et al. 2010; Chen et al. 2010). The number of visitors in subterranean environments has an influence on both microorganism concentrations and compositions (Salmon et al. 1995; Docampo et al. 2011; Wang et al. 2010) as normal indoor and enclosed conditions, with high relative humidity, provide a suitable environment for the colonization and growth of bacteria and fungi (Bastian et al. 2010). However, there are no previous works combining aerobiological studies with detailed monitoring of the underground environment.

Here, we propose a double analytical approach to assess the extent of anthropogenic impacts on a cave atmosphere: first, a spatiotemporal monitoring of the main microclimatic parameters during daily visits, including the control of trace gases $\left(\mathrm{CO}_{2}\right.$ and $\left.{ }^{222} \mathrm{Rn}\right)$ as indicators of cave ventilation and air movement within cave, and second, aerobiological samplings, conducted to quantify the concentration and diversity of airborne microorganisms and their spatial distribution. This study is focused for understanding microorganism dispersion processes and reinforces the importance of an environmental monitoring programme in order to ensure adequate conservation strategies in caves.

\section{Material and methods}

\subsection{Site}

Ardales Cave was discovered in 1821 , open to visitors in 1852 , and the visits discontinued in 1896 . The cave was declared a National Monument in 1931, but no protection was guaranteed. A cave visit was resumed in a controlled way in the year 1992 and historically ranges around 1,000 visitors per year, on average, although 2,640 people visited the cave in the year 2007. This cave is characterized by a moderate to low visitor impact when compared with other caves nearby: Nerja 500,000 visitors, Tesoro 26,000 (Fernández-Cortés et al. 2008). The cave walls and rocks have 1,009 paintings and engravings of animals, humans, and different signs distributed among 251 panels (Cantalejo et al. 2006). Recent studies have been previously reported the presence of metabolically active bacteria on whitish colonizations present in the rock, sediments and speleothems, with a highly significant role of species of the genus Psendonocardia (Stomeo et al. 2008).

\subsection{Microclimate monitoring}

The microenvironmental monitoring system operating in the cave was installed to record the microclimate at different locations (end of the entrance stair, Great Hall and Calvary Gallery, see Fig. 1) and also at the exterior. Each monitoring station consisted of a set of OPUS-200 two-channel datalogger/transmitter (Luff, Fellbach, Germany), used for resistance, current and voltage measurements with high accuracy. Measurements were taken at $1 \mathrm{~m}$ from the floor and recorded every $5 \mathrm{~min}$. Temperature and relative humidity of the air were measured by a humidity and temperature probe (Lufft, model 8160.TFF10), which combines a Pt1000 temperature sensor (measuring range -30 to $70^{\circ} \mathrm{C}$, accuracy $\pm 0.2^{\circ} \mathrm{C}$ and resolution $0.05^{\circ} \mathrm{C}$ ) and a capacitive sensor (measuring range $0 \%$ to $100 \% \mathrm{RH}$, accuracy $\pm 2 \%$ and resolution $0.1 \%$ ). Cave air $\mathrm{CO}_{2}$ concentration was measured using an infrared absorption sensor (Luff 8520) configured over the range $0-3,000 \mathrm{ppm}$, with
Fig. 1 Cross section of Ardales Cave in relation to surface and locations of the microclimatic monitoring stations and aerobiological sampling points

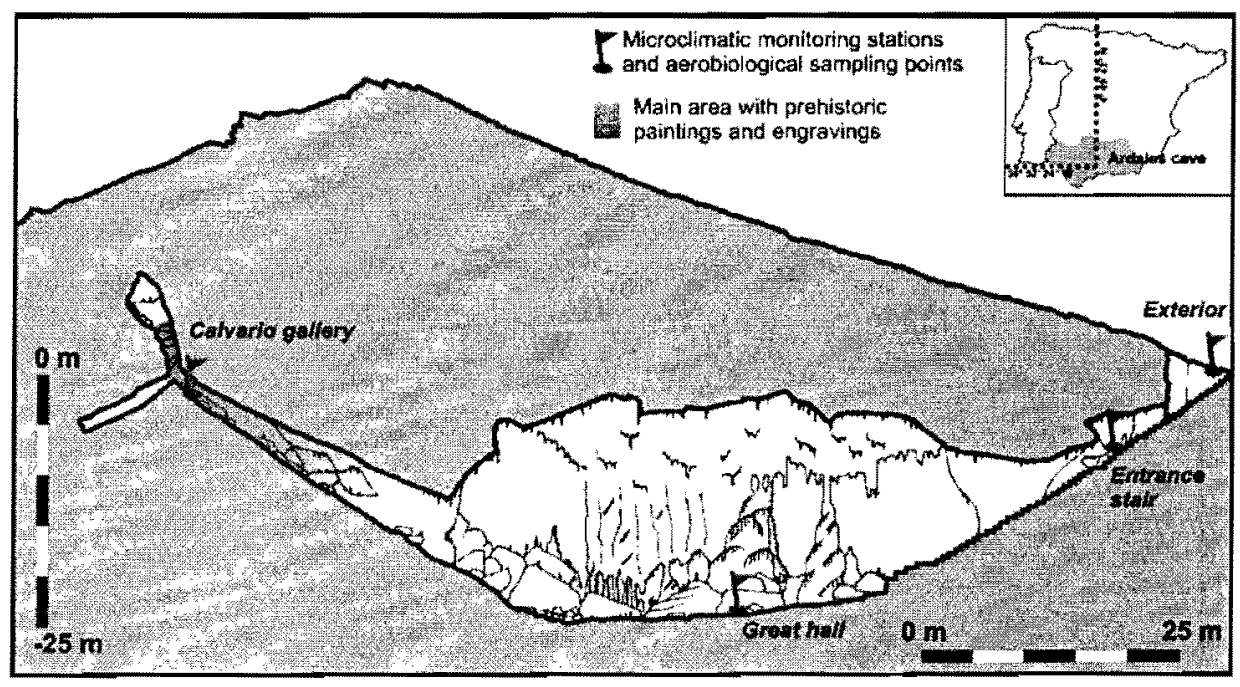


an accuracy of $=2 \%$ of reading and resolution of $=1 \mathrm{ppm}$ (operating range $0-45^{\circ} \mathrm{C}$ and avoiding condensation with a vent microsystem).

The average ${ }^{222} \mathrm{Rn}$ concentration in air was measured at the entrance stair and Calvary Gallery by means of two Radim 5WP radon monitors (GT-Analytik $\mathrm{KG}$, Innsbruck, Austria). The lowest activity detectable is $80 \mathrm{~Bq} / \mathrm{m}^{3}$, for 1 -h measurements with a statistical error equal to $\pm 20 \%$, and the maximum is $150 \mathrm{kBq} / \mathrm{m}^{3}$. The instrument response is $0.4(\mathrm{imp} / \mathrm{h}) /\left(\mathrm{Bq} / \mathrm{m}^{3}\right)$

The microclimatic disturbance of the cave atmosphere by human presence was assessed by controlling key parameters (temperature, relative humidity and carbon dioxide) during six winter-days (from 2 to 7 February 2008). Thus, four groups visited the cave around the midday during the second day (14 people, $110 \mathrm{~min}$ ), third day (10 people, $120 \mathrm{~min}$ ) and fifth day ( 7 people during $95 \mathrm{~min}$, and 4 people during $30 \mathrm{~min}$ and after $60 \mathrm{~min}$ from the preceding visit). During tourist visit, the groups (including a cave guide) are $25 \mathrm{~min}$ in the area of the Great Hall (over two times) and about $15 \mathrm{~min}$ in the area of Calvary. The rest is dedicated to the visit of the Lake Hall and Archer area and $10-15 \mathrm{~min}$ to the entrance and exit of the groups (Fig. 1).

\subsection{Aerobiological study}

An aerobiological sampling was conducted, inside and outside the cave, to quantify the level of airborne bacteria and fungal spores in the same places where the microclimatic system was installed. A Duo SAS 360 sampler (bpInternational, Milan, Italy) containing Petri dishes with Dichloran Rose Bengal Agar was used for the sampling of fungi. This medium facilitates the counting of fungal spores than otherwise would be impossible (King et al. 1979). For bacteria, the medium Tryptone-Soya Agar (TSA) was used. Air volume sampled was $100 \mathrm{~L}$. This volume was selected, among several others tested, as the most appropriate for an easy counting in this cave. Samples were taken in duplicate. The dishes were incubated at $25^{\circ} \mathrm{C}$, and the fungi were isolated as pure culture in malt extract--agar and kept at $5^{\circ} \mathrm{C}$ until further study. For bacteria, the dishes were incubated at $28^{\circ} \mathrm{C}$ and isolated in TSA medium.

\subsection{Molecular methods}

DNA extraction, PCR amplification of DNA, sequencing and phylogenetic analysis have been extensively described elsewhere, either for bacteria (Laiz et al. 2009) or for fungi (Jurado et al. 2010). Accession numbers of strains described in this paper are FR848405-FR848426 for bacteria and FR799474-FR799479 and FR799505FR799510 for fungi.

\section{Results and discussion}

An experimental approach involving the control of microclimatic parameters during the visit of a selected number of people to Ardales Cave was carried out during winter in three different cave areas. In response to the cave geomorphology, the sensors were installed at the end of the entrance stair, Great Hall and in the top of the Calvary Gallery (Fig. 1). An increase in air temperature and $\mathrm{CO}_{2}$ concentration due to visits was only noticed in the Calvary Gallery, the highest cave level in occasion of the visits, and was proportional to the number of people (14 visitors: $+0.17^{\circ} \mathrm{C}$ and $+203 \mathrm{ppm}$ $\mathrm{CO}_{2} ; 10$ visitors: $+0.10^{\circ} \mathrm{C}$ and $+162 \mathrm{ppm} \mathrm{CO}_{2}$; and 7 visitors: $+0.06^{\circ} \mathrm{C}$ and $+115 \mathrm{ppm} \mathrm{CO}_{2}$ ). A small group of four visitors during 30 min do not seem to cause a significant microclimatic impact. Recovery time after daily visits reaches the early morning of the next day (Fig. 2).

One of the most important data is the temperature difference between the three areas monitored. The air temperature in Calvary Gallery $\left(17.45^{\circ} \mathrm{C}\right)$ remains well above the air temperature in the entrance $\left(16.78^{\circ} \mathrm{C}\right)$ and the Great Hall area $\left(16.55^{\circ} \mathrm{C}\right)$. The warming of Calvary coincides with a higher and more stable concentration of ${ }^{222} \mathrm{Rn}$ during the period monitored $\left(12,000-14,000 \mathrm{~Bq} / \mathrm{m}^{3}\right)$, higher than the $6,000-9,000 \mathrm{~Bq} / \mathrm{m}^{3}$ in the entrance area (Fig, 3).

Calvary Gallery is nearby to the surface and topographically higher than the rest of areas. Microenvironmental data show that it operates as a motionless atmosphere that practically does not take part in the aerodynamic process between cave and the external atmosphere. The trap of $\mathrm{CO}_{2}$ gas in the Calvary Gallery is essentially due to its accumulation ncar a gas source identified as the $\mathrm{CO}_{2}$ exhalation of the successive groups of visitors in this area of the cave (Fig. 3a). The coeval air thermal stratification that creates a motionless trap of warm and less dense air contributes to the gas entrapment process in the Calvary Gallery, and it is controlled by the cave geomorphologic features. Here, diffusivity must play the major role in the exchange of $\mathrm{CO}_{2}$ between the air parcels from Calvary Gallery and other deeper and nearby areas of the cave as the Great Hall. A gradient in the molar fraction of gases in both air parcels favours to launch a net transport of gas from high to low $\mathrm{CO}_{2}$ concentrations. Consequently, the recovery of the $\mathrm{CO}_{2}$ levels in the Calvary's atmosphere after the presence of visits is followed, with a certain delay, by an upward trend of the $\mathrm{CO}_{2}$ level in the air parcel of the Great Hall (Fig. 2).

Contrarily to the time evolution of $\mathrm{CO}_{2}$ levels, no thermal impact was noticed in the Great Hall's atmosphere after the tourist visits. Warmer and moist air breathed out by visitors tends to move towards the Great Hall's roof, so none rise of air temperature was registered by the monitoring station. Likewise, the anthropogenic air parcel 
Fig. 2 Detailed time series of the microclimatic conditions in Ardales Cave during a sequence of daily visits. Several environmental impacts are distinguished (see text); $\mathrm{CO}_{2}$ entrapment thermal stratification of the atmosphere in Calvary Gallery and $\mathrm{CO}_{2}$ diffusion from upper to deeper areas (represented by dashed black arrows)

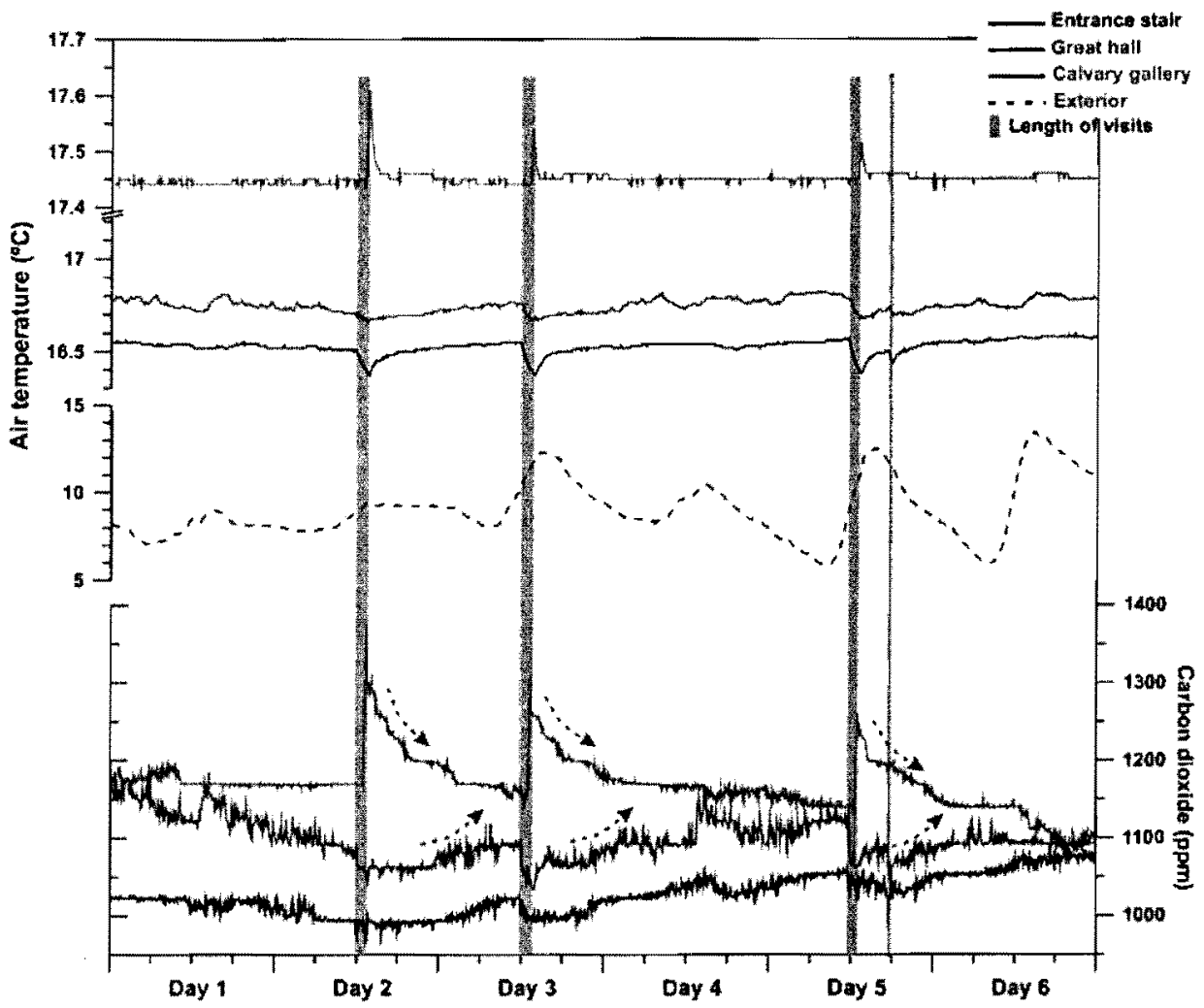

On the other hand, cave air ventilation is forced during time intervals with tourist visits due to the door opening. This effect is marked at the beginning of the visits and
Fig. 3 a Scheme of

human-induced disturbance of the cave environment (foreed ventilation by opening of the cave entrance and local impact of visitors by extra contribution of $\mathrm{CO}_{2}$, water vapour, and dispersion of airborne fungal spores and bacteria). b Detailed time series of ${ }^{222} \mathrm{Rn}$ content of air during a sequence of daily visits

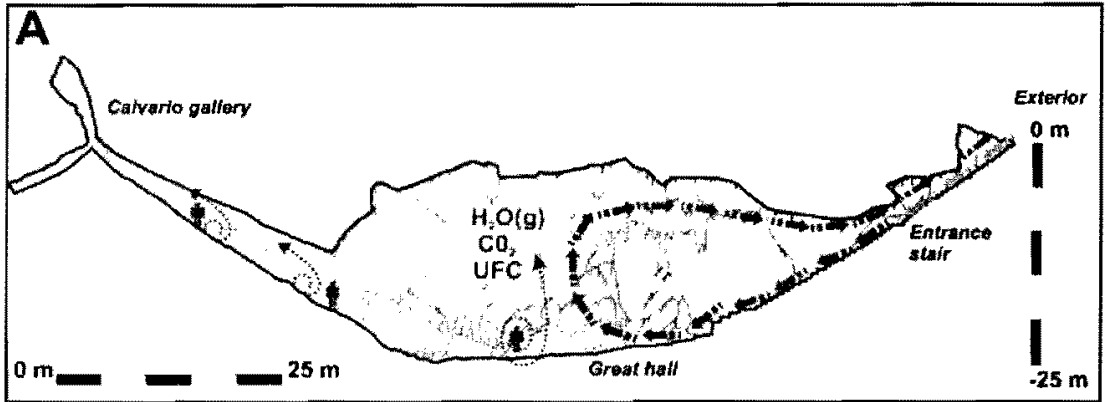

B

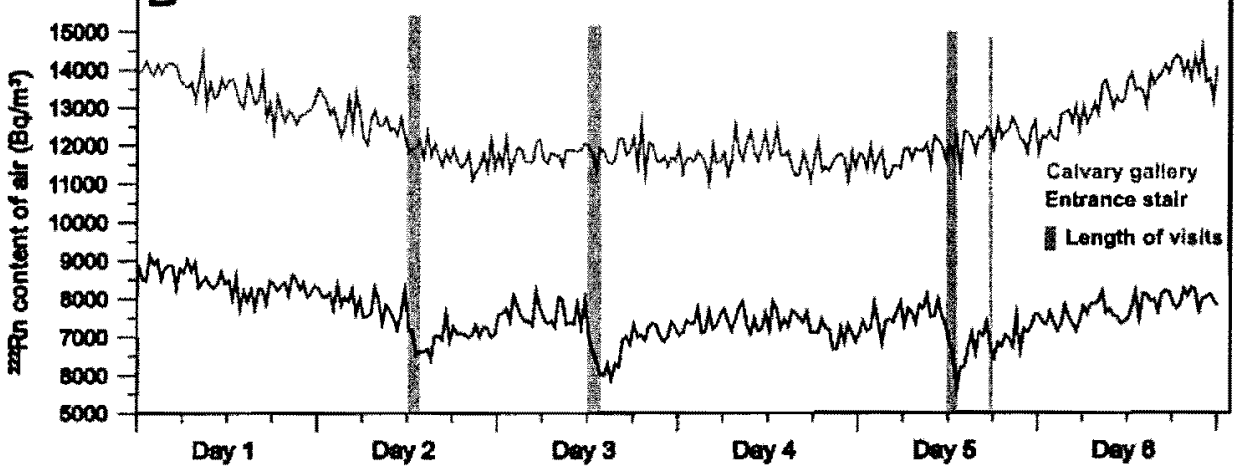


while the cave air temperature is above the temperature of the external atmosphere. A convective air circulation along a thermo-density gradient is established. Accordingly, the influx of colder and denser air from the exterior into the cave is favoured, and simultaneously, the warmer, less dense and inner air parcels evacuate the cave. This humaninduced ventilation provokes a short-term shift of the air temperature, $\mathrm{CO}_{2}$ and ${ }^{222} \mathrm{Rn}$ levels in the cave atmosphere, mainly in those areas with direct connection to the cave entrance: entrance stair and Great Hall (Fig. 3b).

Aerobiology measurements (Tables 1 and 2) in two different days, one immediately after a visit of 32 people during $90 \mathrm{~min}$ and the second after a period of 2 days of cave resting, without visits, illustrate the impact of the visitors on the concentration of bacteria and fungal spores in the cave air. Regarding fungal spores, and according to what was observed in the microenvironmental monitoring, the highest impact was noticed in the Calvary Gallery, while in the Great Hall was very low. It is noteworthy that a visit multiplied the concentration of fungal spores by a factor of 100 in the Calvary, which revealed to be the most disturbed area, and by a factor of 4 at the end of the entrance stair, while remained constant in the Great Hall due to the high size and volume of this hall. These data agree well with those obtained for $\mathrm{CO}_{2}$ concentration and temperature and are of importance because the main rock art paintings and engravings are located in the proximity of the Calvary Gallery, which is the area denoting the most disturbing conditions after visits.

The main fungal genera in cave air corresponded to Aspergillus, Penicillium and Cladosporium. These are also the most abundant fungi in indoor and outdoor samplings (Docampo et al. 2011). The presence of Cladosporium at the end of the cave points to a strong influence of the opening of cave door and the establishment of air flow from outside to inside, during the visit events, sweeping along the fungal spores. The Cladosporium spore number decreases from the entrance to the end of the cave. On the contrary, Penicillium spore number is high inside the cave and concentrates in the Calvary Gallery, the end of the cave. Supporting our observations, Docampo et al. (2011) reported that Aspergillus and Penicillitum are the most abundant fungal genera indoor. This was also the trend found in this cave, particularly when the number of visitors was high and the stream of air maximized, and explains the presence of Alternaria, an outdoor fungus, in the Calvary Gallery, as well. The two most abundant species inside the cave, in terms of spore concentrations, were Penicillitum chrysogenum and Penicillium corylophilum. Both Penicillitum species have been reported in caves all over the world (Grishkan et al. 2004; Semikolennykh et al. 2005; Nováková 2009; Vaughan et al. 2011). Cladosporium cladosporioides was comparatively less frequent inside the cave.
The fungal spores identified after the days without visits show a different behaviour. In fact, the amounts of Aspergillus, Penicillium and Cladosporium are low at the end of the entrance stair and in the Great Hall. However, the identification of Arthrinium in the undisturbed Calvary Gallery the days without visits is of interest. This is a cosmopolitan fungus found in soils and decomposing plant material, which spores are dispersed by wind. Arthrinium was previously reported in the air, sediment, bat guano and earthworm casts of Slovakian caves (Nováková 2009), and was abundantly represented in Kartchner Caverns, Arizona (Vaughan et al. 2011). In Ardales Cave, the presence of bats and rodents as well as small animals was registered in the frequent surveys, and a similar origin (animal excrements) for this fungus is possible.

In general, fungal aerobiology data reflect the importance of the opening of the door for the visits, and the time that remains open, in the cave bioaerosol composition. In addition, this contributes to the emission/dispersal mechanisms of fungi through conidiophores or asci.

The aerobiological behaviour of bacteria is different. We might expect caves to have a significant influence on the airborne bacteria due to the specific nature of the communities found on speleothems and rocks. Bacteria are found in this cave coating stalactites, stalagmites, rocks and sediments (Stomeo et al, 2008). The data show that after an opening of the door and visit, the concentration of outdoor bacteria (lower than inside) does not justify the increasing amount found in the entrance stair and Great Hall. This increase is likely produced because the visits when descending the stair steps, which by the way showed abundant bacterial colonization, as well as the stalactites and stalagmites, originate great turbulences and erosions involving mechanical removal of sediment particles, which are much larger than the size of single bacterial cells or fungal spores. When the cave was non-visited for a few days, the higher bacteria concentration is found in the Great Hall. We have observed in this hall that the area where the sensors were installed has a rodent maximum activity (up to 20 excrements by square metre were found there). In absence of visits, rodent activities would maximize.

The composition of the culturable airborne bacteria inside the cave is remarkable. These are mainly represented by Gram-positive bacteria, ranging from $82.4 \%$ to $100 \%$. Outdoors, the range is $50.4-81.2 \%$. It has been reported that spore-forming organisms, such as Bacillus species and other Gram-positives, tend to dominate airborne microbial diversity (Mancinelli and Shulls 1978). While practically Bacillus spp. are represented in all the sampling stations, there are differences regarding the presence or absence of visitors. In fact, the higher percentages of spores can be found the days with visits, particularly in the Great Hall. After the visits, the Calvary Gallery shows a concentration 
Table 1 Concentration of fungal spores as colony forming units $\mathrm{CFU} / \mathrm{m}^{3}$ during two sampling surveys with different scenarios, one immediately after a visit of 32 people and the second after a period of 2 days resting without visits

\begin{tabular}{|c|c|c|c|c|c|c|c|c|c|c|}
\hline \multirow[t]{3}{*}{ Hall/Gallery } & \multicolumn{5}{|c|}{ After a visit } & \multicolumn{5}{|c|}{ Without visits } \\
\hline & \multicolumn{2}{|l|}{$\mathrm{CFU} / \mathrm{m}^{3}$} & \multirow[t]{2}{*}{ Fungi identified } & \multirow[t]{2}{*}{$\%$ Similarity } & \multirow[t]{2}{*}{$\%$ Abundance } & \multicolumn{2}{|l|}{$\mathrm{CFU} / \mathrm{m} 3$} & \multirow[t]{2}{*}{ Fungi identified } & \multirow[t]{2}{*}{$\%$ Similarity } & \multirow[t]{2}{*}{$\%$ Abundance } \\
\hline & Average & SD & & & & Average & SD & & & \\
\hline \multirow[t]{2}{*}{ Calvary gallery } & \multirow[t]{2}{*}{1,010} & \multirow[t]{2}{*}{100} & $\begin{array}{l}\text { Penicillium chrysogenum } \\
\text { Alternaria } \mathrm{sp} .1\end{array}$ & $\begin{array}{l}100 \\
98\end{array}$ & $\begin{array}{r}97.8 \\
1.6\end{array}$ & \multirow[t]{2}{*}{10} & \multirow[t]{2}{*}{7.0} & \multirow[t]{2}{*}{ Arthrinium sp. } & \multirow[t]{2}{*}{99} & \multirow[t]{2}{*}{100} \\
\hline & & & Cladosporium sp. 1 & 100 & 0.6 & & & & & \\
\hline \multirow[t]{3}{*}{ Great hall } & \multirow[t]{3}{*}{40} & \multirow[t]{3}{*}{0} & Aspergillus sp. 1 & 100 & 75.0 & \multirow[t]{3}{*}{40} & \multirow[t]{3}{*}{21.2} & Penicilitium sp. 1 & 99 & 35.0 \\
\hline & & & Cladosporium cladosporioides & 100 & 25.0 & & & Cladosporitu cladosporioides & 100 & 32.5 \\
\hline & & & & & & & & Aspergillus sp. 1 & 100 & 32.5 \\
\hline \multirow[t]{3}{*}{ Entrance stair } & \multirow[t]{3}{*}{330} & \multirow[t]{3}{*}{28.2} & Penicillium corylophilum & 100 & 71.8 & \multirow[t]{3}{*}{80} & \multirow[t]{3}{*}{84.9} & Aspergillus sp. 1 & 100 & 62.5 \\
\hline & & & Penicillium chrysogenum & 100 & 18.8 & & & Penicilium chrysogenum & 100 & 37.5 \\
\hline & & & Cladosporium cladosporioides & 100 & 9.4 & & & & & \\
\hline \multirow[t]{6}{*}{ Outdoor } & \multirow[t]{6}{*}{620} & \multirow[t]{6}{*}{40.0} & Cladosporitum cladosporioides & 100 & 51.6 & \multirow[t]{6}{*}{50} & \multirow[t]{6}{*}{7.0} & Cladosporium sp. 2 & 100 & 30.0 \\
\hline & & & Cladosporium cucumericum & 99 & 42.6 & & & Cladosporium cladosporioides & 100 & 30.0 \\
\hline & & & Penicillium digitatum & 100 & 5.8 & & & Alternaria alternata & 98 & 10.0 \\
\hline & & & & & & & & Penicillium sp. 2 & 99 & 10.0 \\
\hline & & & & & & & & Alternaria sp. 1 & 98 & 10.0 \\
\hline & & & & & & & & Chalara microchona & 99 & 10.0 \\
\hline
\end{tabular}

$S D$ standard deviation

The numbers represent the average value and standard deviation of two repeats 
Table 2 Concentration of bacteria as colony forming units $\mathrm{CFU} / \mathrm{m}^{3}$ during two sampling surveys with different scenarios, one immediately after a visit of 32 people and the second after a period of 2 days resting without visits

\begin{tabular}{|c|c|c|c|c|c|c|c|c|c|c|}
\hline \multirow[t]{3}{*}{ Hall/Gallery } & \multicolumn{5}{|c|}{ After a visit } & \multicolumn{5}{|c|}{ Without visits } \\
\hline & \multicolumn{2}{|l|}{$\mathrm{CFU} / \mathrm{m}^{3}$} & \multirow[t]{2}{*}{ Bacteria identified } & \multirow[t]{2}{*}{$\%$ Similarity } & \multirow[t]{2}{*}{$\%$ Abundance } & \multicolumn{2}{|l|}{$\mathrm{CFU} / \mathrm{m}^{3}$} & \multirow[t]{2}{*}{ Bacteria identified } & \multirow[t]{2}{*}{$\%$ Similarity } & \multirow[t]{2}{*}{$\%$ Abundance } \\
\hline & Average & SD & & & & Average & $\mathrm{SD}$ & & & \\
\hline \multirow[t]{4}{*}{ Calvary gallery } & \multirow[t]{4}{*}{60} & \multirow[t]{4}{*}{70.7} & Bacillus sp. 1 & 99 & 65.0 & \multirow[t]{4}{*}{10} & \multirow[t]{4}{*}{7.1} & \multirow{4}{*}{ Arthrobacter sp. } & \multirow[t]{4}{*}{98} & \multirow[t]{4}{*}{100} \\
\hline & & & Escherichia coli & 99 & 11.7 & & & & & \\
\hline & & & Streptomyces sp. 1 & 98 & 11.7 & & & & & \\
\hline & & & Streptomyces zaomyceticus & 99 & 11.6 & & & & & \\
\hline \multirow[t]{8}{*}{ Great hall } & \multirow[t]{8}{*}{330} & \multirow[t]{8}{*}{205.1} & Bacillus sp. 1 & 98 & 35.1 & \multirow[t]{8}{*}{580} & \multirow[t]{8}{*}{572.8} & Streptomyces avidinit & 99 & 80.5 \\
\hline & & & Bacillus sp. 2 & 98 & 29.7 & & & Paracocaus sp. & 99 & 9.3 \\
\hline & & & Micrococcus luteus & 99 & 17.6 & & & Escherichia coli & 99 & 1.7 \\
\hline & & & \multirow{5}{*}{ Hydrogenophaga intermedia } & \multirow[t]{5}{*}{98} & \multirow[t]{5}{*}{17.6} & & & Bacillus sp. 1 & 99 & 1.7 \\
\hline & & & & & & & & Pseudomonas vancouverensis & 99 & 1.7 \\
\hline & & & & & & & & Streptomyces zaomyceticus & 99 & 1.7 \\
\hline & & & & & & & & Bacillus simplex & 99 & 1.7 \\
\hline & & & & & & & & Bacillus sp. 3 & 98 & 1.7 \\
\hline \multirow[t]{9}{*}{ Entrance stair } & 430 & 367.7 & Streptomyces zaomyceticus & 99 & 37.2 & 150 & 127.3 & Streptomyces avidinii & 99 & 41.3 \\
\hline & & & Bacillus simplex & 99 & 28.5 & & & Microbacterium phyllosphaerae & 99 & 24.0 \\
\hline & & & Escherichia coli & 99 & 4.9 & & & Streptomyces sp. 2 & 99 & 17.3 \\
\hline & & & Streptomyces avidinii & 99 & 4.9 & & & Bacillus simplex & 99 & 8.7 \\
\hline & & & Bacillus idriensis & 99 & 4.9 & & & Arthrobacter methylotrophws & 98 & 8.7 \\
\hline & & & Bacillus sp. 2 & 98 & 4.9 & & & & & \\
\hline & & & Bacillus weihenstephanensis & 99 & 4.9 & & & & & \\
\hline & & & Arthrobacter methylotrophus & 99 & 4.9 & & & & & \\
\hline & & & Paenibacillus lautus & 98 & 4.9 & & & & & \\
\hline Outdoor & 120 & 42.4 & Acinetobacter sp. & 99 & 35.5 & 170 & 120.2 & Oerskovia paurometabola & 99 & 25.3 \\
\hline & & & Lysimibacillus sphaericus & 99 & 21.5 & & & Escherichia coli & 98 & 20.0 \\
\hline & & & Streptomyces sp. 2 & 97 & 21.5 & & & Bacillus sp. 1 & 99 & 14.1 \\
\hline & & & Shigella sonnei & 99 & 14.1 & & & Bacillus simplex & 100 & 13.5 \\
\hline & & & Bacillus simplex & 100 & 7.4 & & & Rothia amarae & 99 & 12.9 \\
\hline & & & & & & & & Planococcus sp. & 99 & 7.1 \\
\hline & & & & & & & & Arthrobacter tumbae & 99 & 7.1 \\
\hline
\end{tabular}

SD standard deviation

The numbers represent the average value and standard deviation of two repeats 
lower than the Great Hall, but four times higher than the Great Hall without visits. It is remarkable that the nunber of Bacillus spores is low when the cave was non-visited. This behaviour mimics the one reported for fungi and can be interpreted as that Bacillus spores suffer a similar dispersion pattern than fungal spores, while other bacteria are likely dispersed by particles.

On the other hand, the species of the genera Arthrobacter, Micrococcus, Pseudomonas, etc. have no relevant patterns and can be occasionally scattered in a hall or gallery. Most bacteria have no other dispersal mechanism than that derived from wind speeds, turbulences, impacts or splashes of falling drops from the stalactites and the ceiling on the sediments, etc. The activity of small animals (rodents, bats) and humans inside the cave can be a source of particles removal and emission to the atmosphere as well. Shaffer and Lighthart (1997) stated that the majority of airbome bacteria are associated with particles and they may occur as agglomerations of cells. In addition, it has been reported that high concentrations of airborne bacteria can be found after a simulated rainfall (Robertson and Alexander 1994).

Escherichia coli merits some comments. This bacterium has a relative abundance outdoors $(20 \%)$ as corresponds to an area of cattle farming in the topsoil and cave surroundings. This has been found randomly distributed in all the stations, irrespective of the visits. Also, rodents and bats activities inside the cave can contribute to its dispersion.

In a previous paper, it was stated that the phylum Actinobacteria was the most frequently found in the analysed 16S rRNA gene library of the speleothems of this cave, reaching $44 \%$ of sequences out of a total of 25 clones (Stomeo et al. 2008). Within the Actinobacteria, most of the clones corresponded to microorganisms belonging to Streptomyces, the Rubrobacteridae, and a high proportion of them to the genus Pseudonocardia. Unfortunately, the number of clones used by Stomeo et al. (2008) was too low for deriving ecological consequences or for comparing with the aerobiology data. Anyway, the presence of species of Streptomyces, and particularly Streptomyces avidinii and Streptomyces zaomyceticus in different cave compartments, is of interest and suggests that members of this genus are actually involved in the colonization of speleothems. No culturable Pseudonocardia were found in the aerobiological study. It is well known that the vast majority of environmental bacteria are non-culturable. This may be particularly true for airborne bacteria since the culturability of bacteria rapidly decreases following aerosolization (Heidelberg et al. 1997).

\section{Conclusions}

This paper shows for the first time data obtained from a combination of microclimate and aerobiological monitoring in caves and reveals that the human presence in Ardales Cave results in the entrapment of warmer, less dense and $\mathrm{CO}_{2}$-enriched air at the Calvary Gallery, as well as a strong increase of airborne fungal spores.

The energy released in the air parcel of Calvary Gallery due to visit's impact creates a thermal sedimentation that traps air in the hot bubble and only diffusion can evacuate $\mathrm{CO}_{2}$ from there, since the cave entrance is far and the convective air circulation is mitigated.

Human-induced variations of the cave microclimate by opening of the entrance entail the local air movement and, therefore, reinforce the role of the atmosphere as a vehicle for the transport and dispersion of airbome microorganisms and nutrients inside the cave. Furthermore, visits originate the transfer of airborne fungal spores to endangered areas such as the Calvary Gallery.

The mobilization of airbome microorganisms and the extra contribution of water vapour, temperature and $\mathrm{CO}_{2}$ caused by visitors could activate rock surface weathering, including those with prehistoric paintings and engravings.

The detection of evident anomalies in the cave area housing the high density of paintings and engravings helps to control human disturbances and supports the direct application of this double approach for cave management purposes.

Acknowledgements This research was supported by the Spanish Ministry of Science, projects CGL2010-17108/BTE and CGL200805929. The funding of Consejeria de Cultura and Consejeria de Innovacion, Ciencia y Empresa, Junta de Andalucia, project RNM5137, is acknowledged. A. Fernandez-Cortes benefits from the JAEDoc Program (CSIC) and S. Cuezva from a Juan de la Cierva fellowship. The Museum of Prehistory of Ardales and its staff are acknowledged for their constant and invaluable collaboration. This is a TPC Consolider CSD2007-00058 paper.

\section{References}

Andrieux C (1988) Influence de l'homme sur l'environnement climatique souterrain. Mémoires du Spéléo-Club de Paris, $n^{\circ} 14$, Actes des Journées Félix Trombe T-1, 98-122

Bastian F, Alabouvette C, Saiz-Jimenez C (2009) Impact of biocide treatments on the bacterial communities of the Lascaux Cave. Naturwissenschaften 96:863-868

Bastian $F$, Jurado $V$, Novakova $A$, Alabouvette $C$, Saiz-Jimenez $C$ (2010) The microbiology of the Lascaux Cave. Microbiology I56:644-652

Cantalejo P, Maura R, Espejo MM, Ramos JF, Medianero J, Aranda A, Durán JJ (2006) La Cueva de Ardales. Arte prehistórico y ocupación en el Paleolítico Superior. Centro de Ediciones de la Díputación Provincial, Málaga

Chen Y-P, Cui Y, Dong J-G (2010) Variation of airbome bacteria and fungi at Emperor Qin's Terra-Cotta Museum, Xi'an, China, during the "Oct I" gold week period of 2006. Environ Sci Pollut Res 17:478-485

Docampo S, Trigo MM, Recio M, Melgar M, García-Sánchez J, Cabezudo B (2011) Fungal spore content of the atmosphere of 
the Cave of Nerja (southern Spain): diversity and origin. Sci Total Environ 409:835-843

Dreybrodt $W_{4}$ Gabrovsek F, Perne M (2005) Condensation corrosion a theoretical approach. Acta Carsol 34:317, 348

Faimon J, Stelel J, Sas D (2006) Anthropogenic $\mathrm{CO}_{2}$-flux into cave atmosphere and its environmental impact. A case study in the Cisarska Cave (Moravian Karst Crech Republic). Sci Total Environ 369:231-245

Fernandez-Cortes A, Calaforra IM, Sanchez-Martos F (2006) Spatiotemporal analysis of air microclimatic conditions a tool for show cave environmental management (Cueva del Agua Spain). Atmos Environ 40:7378-7394

Femández-Cortés A, Calaforra JM, Martín-Rosales W, González-Ríos MJ (2008) Cavidades turisticas de Andalucia. In: Calaforra JM, Berrocal JA (eds) El Karst de Andalucía (Geoespeleología Bioespeleologia y Presencia Humana). Consejería de Medio Ambiente de la Junta de Andalucía, Sevilla 105-115

Grishkan I, Nevo E, Wasser SP (2004) Micromycetes from the saline Arubotaim Cave: Mount Sedom, the Dead Sea Southwestern Shore, Israel. J Arid Environ 57:431 443

Heidelberg J, Shahamat M, Levin M, Rahman I, Stelma G, Grim C, Colwell R (1997) Effect of aerosolization on culturability and viability of gram-negative bacteria. Appl Environ Microbiol 63:3585-3588

Hill $C$, Forti $P$ (1997) Cave minerals of the world. National Speleological Society, Huntsville

Hoyos M, Soler V, Cañaveras JC, Sanchez-Moral S, Sanz-Rubio E (1998) Microclimatic characterization of a karstic cave human impact on microenvironmental parameters of a prehistoric rock ant cave (Candamo Cave northern Spain). Environ Geol 33:231--241

Huppert G, Burti E, Forti P, Cigna AA (1993) Effects of tourist development on caves and karst. In: Williams PW (ed) Karst Terrains. Environmental Changes and Human Impact. Catena Supplement 25 pp. 251-268

Jurado V, Laiz, L, Rodriguez-Nava V, Boiron P, Hermosin B, SanchezMoral S, Saiz-Jimenez C (2010) Pathogenic and opportunistic microorganisms in caves. Int J Speleol 39:15-24

King AD, Hocking AD, Pitt JI (1979) Dichloran-rose bengal medium for enumeration and isolation of molds from foods. Appl Environ Microbiol 37:959-964

Laiz L, Miller AZ, Jurado V, Akatova E, Sanchez-Moral S, Gonzalez JM, Dionisio A, Macedo MF, Saiz-Jimenez C (2009) Isolation of five Rubrobacter strains from biodeteriorated monuments. Naturwissenschaften 96:71-79
Mancinelli RL, Shulls WA (1978) Airbome bacteria in an urban environment. Appl Environ Microbiol 35:1095-1101

Nováková A (2009) Microscopic fungi isolated from the Domica Cave system (Slovak Karst National Park Slovakia). A review. Int J Speleol 38:71-82

Rintala H, Pitkäranta M, Toivola M, Paulin L, Nevalainen A (2008) Diversity and seasonal dynamics of bacterial community in indoor environment. BMC Microbiology 856 doi 10.1186 i $1471-2180-8-56$

Robertson BK, Alexander M (1994) Mode of dispersal of the stemnodulating bacterium, Azorhizobium. Soil Biol Biochem $26: 1535-1540$

Salmon LG, Christoforou CS, Gerk TJ, Cass GR, Casuccio GS, Cooke GA, Leger M, Olmez I (1995) Source contributions to airborne particle deposition at the Yungang Grottoes China. Sci Total Environ 167:33 47

Sanchez-Moral S, Soler V, Cañaveras JC, Sanz-Rubio E, Van Grieken R, Gysels K (1999) Inorganic deterioration affecting the Altamira Cave N Spain. Quantitative approach to wall-corrosion (solutional etching) processes induced by visitors. Sci Total Environ 243 (244):67-84

Sanchez-Moral S, Luque L, Cuezva S, Soler V, Benavente D, Laiz L, Gonzalez JM, Saiz-Jimenez C (2005) Deterioration of building materials in Roman catacombs. The influence of visitors. Sci Total Environ 349:260-276

Semikolennykh AA, Ivanova AE, Dobrovolskaja TG, Gorlenko MV (2005) Soil and gypsum caves microbial communities of karstogenic landscapes of Archangelsk Region (Russia). Proceedings 14 th International Congress of Speleology, Hellenic Speleological Society, Athens. 642-646

Shaffer BT, Lighthart B (1997) Survey of the culturable airbome bacteria at four diverse locations in Oregon: urban, rural, forest and coastal. Microb Ecol 34:167-177

Stomeo F, Portillo MC, Gonzalez JM, Laiz L, Saiz-Jimenez C (2008) Pseudonocardia in white colonizations in two caves with Paleolithic paintings. Int Biodeterior Biodegrad 62:483-486

Vaughan MJ, Maier RM, Pryor BM (2011) Fungal communities on speleothem surfaces in Kartchner Caverns, Arizona, USA. Int J Speleol 40:65-77

Wang W, Ma X, Ma Y, Mao L, Wu F, Ma X, An L, Feng H (2010) Seasonal dynamies of airborne fungi in different caves of the Mogao Grottoes Dunhuang China. Int Biodeterior Biodegrad $64: 461-466$ 